\title{
CONFIRMATORY FACTOR ANALYSES OF ADOLESCENT EDUCATION CHARACTER BY FAMILIES/PARENTS IN PREMARITAL SEXUAL PREVENTION IN JEMBER, INDONESIA
}

\author{
Iis Rahmawati ${ }^{1 *}$, Dewi Suminar Retno ${ }^{2}$, Oedojo Soedirham ${ }^{3}$, Pingky Saptandari $W^{4}$ \\ ${ }^{1}$ Student Doctor Degree Health Sciences Faculty of Public Health, Airlangga University, Indonesia \\ ${ }^{2}$ Lecturer in Psychology, Airlangga University, Indonesia \\ ${ }^{3}$ Lecturer in Anthropology, Airlangga University, Indonesia \\ ${ }^{4}$ Lecturer in School of Public Health, Airlangga University, Indonesia \\ *e-mail:iis_r.psik@unej.ac.id
}

\begin{tabular}{|c|c|}
\hline & $A B S T R A C T$ \\
\hline $\begin{array}{l}\text { Keywords: } \\
\text { character educa- } \\
\text { tion of adolescents } \\
\text { by family/parents } \\
\text { enforcement of } \\
\text { rules } \\
\text { habituation } \\
\text { imitating } \\
\text { motivating } \\
\text { teaching }\end{array}$ & $\begin{array}{l}\text { Adolescents are often involved in various risks of sexual behavior that are detri- } \\
\text { mental to health, social, and economic consequences, therefore parents are the first } \\
\text { and foremost educators for children and have an important role in providing } \\
\text { children's character education to avoid premarital sexual behavior. The research } \\
\text { sample was } 229 \text { students in six high schools in Jember Regency. The study used } \\
\text { multistage random sampling technique. Variables in adolescent character educa- } \\
\text { tion include indicators of teaching, motivating, habituation, modeling and enforce- } \\
\text { ment of rules. Data analysis uses confirmatory factor analyze (CFA) with data esti- } \\
\text { mation parameters using software (analysis of moment structures (AMOS) version } \\
\text { 21). P-value of character education for adolescents by family/parents to teaching } \\
\text { (0.000), p-value of adolescent character education by family/parents to motivation } \\
\text { (0.000), p-value of character education for adolescents by family/parents to study } \\
\text { (0,080), the value of character education for adolescents by family/parents to ha- } \\
\text { bituation (0.000), the value of adolescent character education by family/parents to } \\
\text { enforcement of the rules (0.000). The model fit value in the comparative fit index } \\
\text { (CFI) (0.897). Adolescent character education can be formed through teaching, } \\
\text { motivating, imitating, habituating and enforcing the rules of parents to teenagers. }\end{array}$ \\
\hline
\end{tabular}

\section{ABSTRAK}

\section{Kata kunci:}

pendidikan karakter

remaja oleh keluarga/orang tua pemotivasian peneladanan pembiasaan pengajaran penegakan aturan
Remaja sering terlibat dalam berbagai risiko perilaku seksual yang merugikan kesehatan, social, dan konsekuensi ekonomi, oleh karena itu orang tua sebagai pendidik pertama dan utama bagi anak dan memiliki peran penting dalam memberikan pendidikan karakter anak supaya terhindar dari perilaku seksual pranikah. Sampel penelitian sebanyak 229 siswa di enam sekolah menengah atas di Kabupaten Jember. Penelitian menggunakan tehnik multistage random sampling. Variable pendidikan karakter remaja meliputi indikator pengajaran, pemotivasian, pembiasaan, peneladanan dan penegakan aturan. Analisis data menggunakan confirmatory factor analyze (CFA) dengan parameter estimasi data menggunakan software (analysis of moment structures (AMOS) version 21). P-value pendidikan karakter remaja oleh keluarga/orang tua ke pengajaran $(0,000)$, p-value pendidikan karakter remaja oleh keluarga/orang tua ke pemotivasian $(0,000)$, p-value pendidikan karakter remaja oleh keluarga/orang tua ke peneladanan $(0,080)$, p-value pendidikan karakter remaja oleh keluarga/orang tua ke pembiasaan $(0,000)$, p-value pendidikan karakter remaja oleh keluarga/orang tua ke penegakan aturan $(0,000)$. Nilai fit model pada comparative fit index (CFI) $(0,897)$. Pendidikan karakter remaja dapat 
dibentuk melalui pengajaran, pemotivasian, peneladanan, pembiasaan dan penegakan dari aturan dari orang tua ke anak remaja.

\section{PENDAHULUAN}

Menurut KOMNAS perlindungan anak tahun 2007 bahwa perilaku remaja yang melakukan hubungan seks pranikah cenderung meningkat dan sebanyak 93,7\% anak SMP dan SMU mengaku pernah melakukan ciuman, petting, dan oral sex, sebanyak $62,7 \%$ anak SMP mengaku sudah tidak perawan. Sebanyak $21,2 \%$ remaja SMA mengaku pernah melakukan aborsi dan 97\% anak SMP dan SMA mengaku suka menonton film porno (BKKBN, 2010). Hasil Survei KOMNAS perlindungan anak tahun 2008 menunjukkan bahwa pada 33 Provinsi di Indonesia terdapat $62,7 \%$ remaja SMP tidak perawan dan terdapat $22,6 \%$ remaja yang melakukan seks bebas. Jumlah kejadian seks pranikah dari 500 responden terdapat 370 responden $(74 \%)$ menyatakan responden pernah berpacaran, bahkan 28 responden $(5,6 \%)$ menyatakan sudah pernah melakukan hubungan seksual sebelum menikah.

Berdasarkan sudut pandang kesehatan bahwa tindakan menyimpang yang mengkhawatirkan adalah masalah yang berhubungan dengan seks bebas (unprotected sexuality), penyebaran penyakit kelamin, kehamilan di luar nikah atau kehamilan yang tidak dikehendaki (adolecent unwanted pragnancy) di kalangan remaja. Permasalahan utama ini dapat menimbulkan permasalahan lainnya yaitu aborsi dan pernikahan usia muda. WHO menyebut permasalahan ini sebagai permasalahan kesehatan reproduksi remaja dan mendapatkan perhatian khusus dari berbagai organisasi internasional.

Remaja sering terlibat dalam berbagai risiko perilaku seksual yang merugikan kesehatan, social, dan konsekuensi ekonomi. Remaja memerlukan dukungan keluarga khususnya orang tua, selain fisik juga psikologis. Dukungan finansial menurut Friedman (2003) menjelaskan bahwa status ekonomi merupakan komponen kelas sosial yang menunjukkan tingkat dan sumber penghasilan keluarga. Bahwa kelas sosial ekonomi keluarga diukur dengan tingkat pendidikan, penghasilan, pekerjaan, dan jumlah anggota keluarga. Pendidikan merupakan aspek status sosial yang sangat berhubungan dengan status kesehatan karena pendidikan penting untuk membentuk pengetahuan dan pola perilaku. Jumlah anggota keluarga dalam rumah mempengaruhi pendapatan atau penghasilan. Keluarga besar mempunyai beban lebih besar sehingga kurang memperhatikan kesehatan anggota keluarga karena lebih memperhatikan kebutuhan hidup.

Dukungan psikologis orang tua kepada remaja yaitu sebagai orang terdekat dalam lingkungan keluarga dengan anak untuk mengenal dan memahami jiwa anak secara mendalam agar dapat mendidik, membimbing, serta mengarahkan karakter menuju jalan yang benar dan diridhoi oleh Tuhan. Orang tua memiliki peran sangat penting dalam membina karakter anak karena orang tua sebagai pendidik pertama dan utama. Nilai karakter positif yang bersumber dari ajaran agama harus diberikan, ditanamkan, dan dikembangkan oleh orang tua terhadap anak dalam kehidupan sehari-hari melalui pendidikan karakter remaja di keluarga (Amirullah, 2015).

Menurut Hasanah (2012) bahwa program pendidikan karakter dalam keluarga dapat mencegah perilaku negatif antara lain mencegah perilaku seksual pranikah melalui pengajaran, pemotivasian, peneladanan, pembiasaan dan penegakan aturan. Remaja termasuk kelompok beresiko yaitu terjadi berbagai perubahan dan dibutuhkan kualitas hubungan orang tua terhadap anak remaja dalam berinteraksi. Bila hal tersebut dilaksanakan maka akan memberikan pendidikan karakter pada anak remaja supaya tidak melakukan seksual pranikah. Semakin besar peran orang tua dalam hal berinteraksi dengan anak remaja maka semakin baik tindakan pencegahan orang tua terhadap remaja sehingga output system dari remaja mencapai respons adaptif dan tidak terjadi perilaku seksual pranikah.

\section{METODE}

Penelitian ini dilakukan pada bulan Januari sampai dengan Juni 2018 di Kabupaten Jember, Indonesia. Penelitian ini termasuk cross-sectional approach dengan memakai siswa di beberapa sekolah menengah atas. Kriteria inklusi penelitian meliputi: 1) Sekolah Menengah Atas 5 Jember, Sekolah Menengah Atas Kartika 4 Jember, Sekolah Menengah Keguruan Pancasila Ambulu, Sekolah Menengah Atas Negeri Balung, Sekolah Menengah Atas Islam Kasyan Puger dan Sekolah Menengah Atas 1 Kencong; 2) siswa di 6 sekolah menengah atas yang berusia 16-17 tahun; 3) siswa di 6 sekolah menengah atas yang aktif; 4) siswa di 6 sekolah menengah atas yang berjenis kelamin laki-laki dan perempuan.

Teknik pengambilan sampel menggunakan multistage random sampling karena populasi 
dibatasi menurut kriteria cluster tertentu (sekolah menengah atas). Sampel meliputi siswa $(n=229)$ di SMA 5 Jember, SMA Kartika 4 Jember, SMK Pancasila Ambulu, SMA Balung, SMA Islam Kasyan Puger dan SMA 1 Kencong. Instrumen penelitian menggunakan kuesioner skala likert untuk mengetahui pendidikan karakter remaja oleh keluarga/orang tua tentang pengajaran, pemotivasian, pembiasaan, peneladanan dan penegakan aturan. Teknik pengumpulan data meliputi mengisi format kuesioner pendidikan karakter remaja oleh keluarga/orang tua tentang pengajaran, pemotivasian, pembiasaan, peneladanan dan penegakan aturan. Analisis data menggunakan confirmatory factor analyze (CFA) dengan estimasi data parameter menggunakan perangkat lunak analysis of moment structures (AMOS versi 21) (Byme, 2013). Uji CFA bertujuan untuk mengetahui seberapa baik indikator-indikator pengukuran mengukur sebuah konsep (konstruk) laten dan untuk mengetahui nilai fit model pada comparative fit index (CFI).

\section{HASIL}

Pendidikan karakter remaja oleh keluarga/ orang tua (Y1) diukur melalui 5 aspek indikator yaitu pengajaran (Y1.1), pemotivasian (Y1.2), peneladanan (Y1.3), pembiasaan (Y1.4), penegakan aturan (Y1.5). Hasil analisis secara deskriptif dapat dilihat pada tabel 1.

Variabel dan masing-masing indikator terlihat pada gambar 1 .

Pada gambar 1 menunjukkan bahwa estimasi signifikansi parameter yang dihasilkan oleh karakter remaja oleh keluarga/orang tua ke pengajaran (Y1.1) 1,000. Estimasi karakter remaja oleh keluarga/orang tua ke pemotivasian (Y1.2) 1,687. Estimasi karakter remaja oleh keluarga/orang tua ke peneladanan(Y1.3) 0,391. Estimasi karakter remaja oleh keluarga/orang tua ke pembiasaan (Y1.4) 1,821. Estimasi karakter remaja oleh keluarga/orang tua ke penegakan aturan (Y1.5) 1,572.

\section{Estimasi Signifikansi Parameter}

Tabel 2 menunjukkan bahwa p-value yang dihasilkan untuk relasi karakter remaja oleh keluarga/ orang tua (Y1) ke pengajaran (Y1.1) sebesar 0,000 nilai ini $<0,05$ (alfa $=5 \%$ ) maka pengajaran (Y1.1) dinyatakan signifikan sebagai pengukur konstruk karakter remaja oleh keluarga/orang tua (Y1). Pvalue yang dihasilkan untuk relasi karakter remaja oleh keluarga/orang tua (Y1) ke pemotivasian (Y1.2) sebesar 0,000 nilai ini $<0,05($ alfa $=5 \%)$ maka pemotivasian (Y1.2) dinyatakan signifikan sebagai pengukur konstruk karakter remaja oleh keluarga/ orang tua (Y1). P-value yang dihasilkan untuk relasi karakter remaja oleh keluarga/orang tua (Y1) ke peneladanan (Y1.3) sebesar 0,080 nilai ini $<0,05$ (alfa $=5 \%)$ maka peneladanan (Y1.3) dinyatakan signifikan sebagai pengukur konstruk karakter remaja oleh keluarga/orang tua (Y1). P-value yang dihasilkan untuk relasi karakter remaja oleh keluarga/orang tua (Y1) ke pembiasaan (Y1.4) sebesar 0,000 nilai ini $<0,05($ alfa $=5 \%)$ maka pembiasaan (Y1.4) dinyatakan signifikan sebagai pengukur konstruk karakter remaja oleh keluarga/orang tua (Y1). Pvalue yang dihasilkan untuk relasi karakter remaja oleh keluarga/orang tua (Y1) ke penegakan aturan (Y1.5) sebesar 0,000 nilai ini $<0,05($ alfa $=5 \%)$ maka penegakan aturan (Y1.5) dinyatakan signifikan sebagai pengukur konstruk karakter remaja oleh keluarga/orang tua (Y1).

\section{Nilai Fit Model}

Tabel 3 menunjukkan bahwa nilai indeks fit CFI yang dihasilkan sebesar 0,897 . Karena nilai CFI $<0,90$ maka mengindikasikan bahwa model kurang fit.

\section{PEMBAHASAN}

\section{Pendidikan Karakter Remaja Oleh Keluarga/ Orang Tua Ke Pengajaran}

Hasil penelitian pada tabel 1 menunjukkan bahwa sebagian besar responden tidak pernah mendapatkan pengajaran dari orang tua untuk pencegahan perilaku seksual pranikah sebanyak 142 responden $(62,0 \%)$. Pernyataan yang paling dominan yang tidak pernah dilakukan oleh orang tua terhadap anak remaja yaitu "orang tua saya dalam memberikan pengetahuan tentang seksualitas terlebih dahulu siap dengan alat-alat bantu buku tentang organ tubuh dan fungsi-fungsi reproduksi bergambar". Keluarga merupakan lingkungan pertama dan utama bagi perkembangan anak. Dalam mendidik, ibu dan ayah harus bersikap konsisten, terbuka, bijaksana, bersahabat, ramah, tegas (Gunarsa, 2010). Hasil penelitian menunjukan bahwa sikap seksual orang tua dan konsisten dalam komunikasi orang tua memberikan kontribusi yang signifikan untuk keberhasilan pengembangan diri yang positif pada remaja, sehingga terhindar dari perilaku seksual pranikah (Cheryl, Somers, \& Anagurthi, 2013). Pengetahuan kesehatan seksual yang terbatas dari orang tua mengakibatkan peningkatan resiko infeksi menular seksual (IMS), HIV, kehamilan yang tidak 
Tabel 1. Distribusi Frekuensi Faktor Pencegahan Seksual Pranikah Oleh Keluarga/Orang Tua di Kabupaten Jember tahun 2018

\begin{tabular}{llcccccccc}
\hline \multirow{2}{*}{ No } & Indikator & \multicolumn{9}{c}{ Pernyataan Responden } & & \\
\cline { 3 - 10 } & & \multicolumn{2}{c}{ Tidak } & \multicolumn{2}{c}{ Jarang } & \multicolumn{2}{c}{ Sering } & \multicolumn{2}{c}{ Total } \\
& & $\mathrm{f}$ & $\%$ & $\mathrm{f}$ & $\%$ & $\mathrm{f}$ & $\%$ & $\mathrm{f}$ & $\%$ \\
\cline { 3 - 10 } & & 142 & 62,0 & 67 & 29,3 & 20 & 8,7 & 229 & 100 \\
\hline 1 & Pengajaran & 20 & 8,7 & 83 & 36,2 & 126 & 55,0 & 229 & 100 \\
\hline 2 & Pemotivasian & 135 & 59,0 & 75 & 32,8 & 19 & 8,3 & 229 & 100 \\
\hline 3 & Peneladanan & 38 & 16,6 & 77 & 33,6 & 114 & 49,8 & 229 & 100 \\
\hline 4 & Pembiasaan & 31 & 13,5 & 124 & 54,1 & 74 & 32,3 & 229 & 100 \\
\hline 5 & Penegakan Aturan & & & & & & & & \\
\hline
\end{tabular}

Table 2. Estimasi signifikansi parameter pengajaran, pemotivasian, peneladanan, pembiasaan, dan penegakan aturan

\begin{tabular}{lcc}
\hline \multicolumn{1}{c}{ Variables } & Estimate & $p$-value \\
\hline Y1.1<---- Y1 & 1,000 & 0,000 \\
\hline Y1.2<---- Y1 & 1,687 & 0,000 \\
\hline Y1.3<---- Y1 & 0,391 & 0,080 \\
\hline Y1.4<---- Y1 & 1,821 & 0,000 \\
\hline Y1.5<---- Y1 & 1,572 & 0,000 \\
\hline
\end{tabular}

Table 3. Nilai Fit Model Comparative Fit Index (CFI)

\begin{tabular}{lcc}
\hline & Model & CFI \\
\hline Default model & 0,897 \\
\hline
\end{tabular}

diinginkan dan aborsi serta konsekuensi kesehatan lain.

Pendidikan berasal dari kata "didik", lalu kata ini mendapat awalan "me-" sehingga menjadi "mendidik", artinya memelihara dan memberi latihan, dalam memelihara dan memberi latihan diperlukan adanya ajaran, tuntunan dan pimpinan mengenai ahlak dan kecerdasan pikiran. Pengertian "pendidikan" menurut kamus besar Bahasa Indonesia ialah proses pengubahan sikap dan perilaku seseorang atau kelompok orang dalam usaha mendewasakan manusia melalui upaya pengajaran.

Menurut Ali (2010) orang tua adalah orang yang dianggap tua, cerdik, pandai dalam keluarga yaitu ayah dan ibu. Seorang ayah di samping memiliki kewajiban mencari nafkah bagi keluarga, juga berkewajiban mencari tambahan ilmu bagi dirinya. Seorang ayah dapat membimbing dan mendidik diri sendiri dan keluarga menjadi lebih baik dengan ilmu yang dimiliki. Demikian juga seorang ibu di samping memiliki kewajiban dalam pemeliharaan keluarga, juga memiliki kewajiban mencari ilmu. Hal itu penting karena seorang anak lebih dekat dengan ibu.

Pernyataan dari Program for Appropriate Technology in Health (PATH) yang dikutip Sukaedah (2001) yaitu banyak remaja yang sering kekurangan informasi, pengetahuan, dan akses yang murah untuk mendapatkan pelayaan seputar kesehatan seksual dan ada yang merasa kurang nyaman untuk mendiskusikan dengan orang tua remaja sehingga mengalami resistensi dan sikap yang kurang merespons dari orang dewasa karena dianggap masih tabu ketika remaja mencoba mendapatkan informasi dan layanan kesehatan reproduksi yang dibutuhkan.

Pendidikan seksual merupakan bagian penting dari pendidikan karakter karena seksual adalah tindakan yang penuh dengan konsekuensi (Lickona, 2013). Menurut Sarwono (2011) bahwa pendidikan seksual bukanlah penjelasan tentang seksual semata. Pendidikan seksual sebagaimana pendidikan lain pada umumnya mengandung pengalihan nilai-nilai dari orang tua ke remaja yaitu informasi tentang pendidikan seksual tidak diberikan telanjang melainkan diberikan 


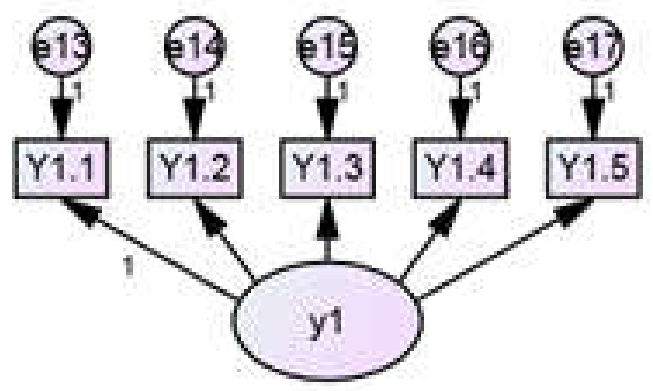

$$
\begin{aligned}
& \text { chi-kuadrat = } \mathrm{lcmin} \\
& \mathrm{df}=\mathrm{ldf} \\
& \mathrm{p} \text {-value }=\mid \mathrm{p} \\
& \text { RMSEA }=\text { Irmsea } \\
& \mathrm{CFI}=\mathrm{lcfi}
\end{aligned}
$$

Gambar 1. Model Hipotesis: Confirmatory Factor Analyze Pendidikan Karakter Remaja Oleh Keluarga/Orang Tua Dalam Pencegahan Seksual Pranikah

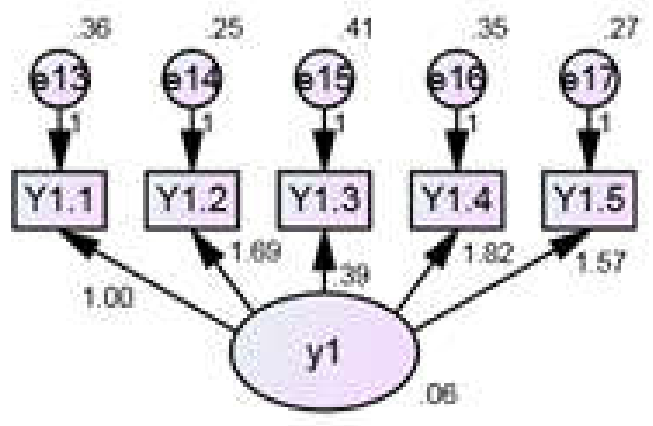

$$
\begin{aligned}
& \text { chi-kuadrat }=17.631 \\
& \text { df }=5 \\
& \text { p-value }=.003 \\
& \text { RMSEA }=.105 \\
& C F I=.897
\end{aligned}
$$

Gambar 2. Confirmatory Factor Analyze Pendidikan Karakter Remaja Oleh Keluarga/Orang Tua Dalam Pencegahan Seksual Pranikah

secara kontekstual, yaitu berhubungan dengan normanorma yang berlaku dalam masyarakat, hal-hal terlarang, hal-hal lazim dan cara melakukan tanpa melanggar aturan. Pandangan yang menyatakan bahwa pendidikan seksual merupakan hal tabu untuk dibahas dengan remaja merupakan hal yang tidak benar. Minimnya pendidikan seksual di kalangan remaja menjadi penyebab tingginya angka praktek seks bebas di kalangan remaja. Terjadinya kasuskasus yang berhubungan dengan seks yang tidak aman di kalangan remaja sebagian besar disebabkan kurang pengetahuan remaja mengenai masalah tersebut. Apabila pengetahuan remaja tentang pendidikan seksual rendah maka yang beredar di kalangan remaja adalah informasi yang tidak dapat dipertanggung jawabkan.

Menurut Nurhayati (2007) bahwa tanggung jawab orang tua tidak hanya mencakup atau terbatas pada kebutuhan materi saja tetapi mencakup seluruh aspek kehidupan anak, termasuk aspek pendidikan seksual karena pendidikan seksual merupakan salah satu pendidikan karakter pada remaja untuk pencegahan seksual pranikah.

Pengetahuan yang diperoleh dari keluarga khususnya orang tua lebih penting karena keluarga merupakan kunci utama dalam menegakkan sikap dan perilaku remaja dalam bermasyarakat. Tujuan pendidikan seksual adalah mendorong keterampilan atau kecakapan, sikap, kecenderungan, perlaku dan refleksi kritis terhadap pengalaman pribadi.

Menurut Forrester dalam Makol-Abduh (2009) menjelaskan bahwa remaja memiliki hak untuk mendapatkan pendidikan seks, materi tersebut sebagai sarana untuk melindungi diri terhadap penyalahgunaan, eksploitasi, kehamilan yang tidak diinginkan, penyakit menular seksual dan HIV/AIDS. Program pendidikan seksual menjadi program gerakan internasional yang bertugas mendukung hak remaja untuk mendapatkan informasi yang akurat dan relevan tentang pendidikan seksual sehingga membantu remaja membuat keputusan mengenai perilaku seksual (Kirby, 2011). Tujuan kesehatan reproduksi remaja yaitu: 1) menurunkan resiko kehamilan dan pengguguran yang tidak dikehendaki; 2) menurunkan resiko IMS/HIV-AIDS; 3) informasi mengenai organ reproduksi dan proses reproduksi serta pentingnya menjaga organ reproduksi dengan baik.

Pengajaran yang diberikan pada remaja untuk mencegah perilaku seksual pranikah. Menurut Qudsy (2012) tujuan dalam memberikan psikoedukasi kepada remaja adalah: 1) penanaman dan pengukuhan ahlak sejak dini kepada anak dan remaja dalam menghadapi masalah seksual agar tidak mudah terjerumus pada pergaulan bebas; 2) remaja mengetahui secara benar tentang seksualitas dan akibatnya jika dilakukan tanpa 
mematuhi aturan; 3) remaja mengetahui aturan berhubungan dengan seksualitas sehingga mampu menjaga kehormatan diri; 4) upaya preventif dalam kerangka moralitas agama untuk menghindarkan remaja dari pergaulan bebas dan penyimpangan seksual; 5) membentuk sikap emosional yang sehat terhadap masalah seksual dan membimbing remaja ke arah hidup dewasa yang bertanggung jawab terhadap kehidupan seksual.

Seks bebas di kalangan remaja disebabkan oleh faktor lingkungan keluarga maupun lingkungan pergaulan. Lingkungan keluarga meliputi cukup tidaknya pendidikan agama yang diberikan orang tua terhadap anak, cukup tidaknya kasih sayang dan perhatian yang diperoleh anak dari keluarga, dan cukup tidaknya keteladanan yang diterima anak dari orang tua. Jika tidak maka anak akan mencari tempat pelarian di jalanan serta di berbagai tempat yang tidak mendidik, anak akan besar di lingkungan yang tidak sehat bagi pertumbuhan jiwa, serta tumbuh di lingkungan pergaulan bebas.

Hasil Penelitian Maryatun \& Purwaningsih (2012) menunjukkan bahwa pengetahuan dan perilaku seksual pranikah memiliki hubungan signifikan. Menurut hasil penelitian Nurkhasanah (2014) menunjukkan bahwa pemberian pendidikan tentang seksual efektif meningkatkan pengetahuan remaja dalam pencegahan perilaku seksual pranikah. Hasil penelitian tersebut didukung oleh penelitian Rahmawati (2017) bahwa pengetahuan remaja yang memadai berpengaruh terhadap perilaku remaja. Semakin baik pengetahuan remaja tentang seksual pranikah maka semakin negatif sikap seksual pranikah remaja. Bahwa remaja yang memperoleh pendidikan seksual memiliki peningkatan pengetahuan dan sikap dibandingkan sebelum memperoleh pendidikan seksual. Hal ini sesuai dengan hasil penelitian Pratama (2014) bahwa responden usia remaja mengenai pengetahuan seksual mempunyai hubungan bermakna dengan perilaku remaja melakukan hubungan seks bebas yaitu $0,000(p<0,01)$ dan nilai $r=0,583$, relasi hubungan yang kuat sehingga disimpulkan semakin baik pengetahuan tentang pendidikan seks maka perilaku seks semakin tidak beresiko. Berarti terdapat hubungan antara pengetahuan remaja tentang pendidikan seks dengan perilaku seks bebas remaja.

\section{Pendidikan Karakter Remaja Oleh Keluarga/ Orang Tua Ke Pemotivasian}

Hasil penelitian mengenai indikator pentingnya pemotivasian orang tua (tabel 1) menunjukan bahwa sebagian besar responden sering mendapatkan pemotivasian dari orang tuaa untuk pencegahan perilaku seksual pranikah yaitu sebanyak 126 responden $(55,0 \%)$. Pernyataan yang paling dominan adalah mengenai "orang tua saya menyampaikan lebih baik fokus ke sekolah dulu, jangan memikirkan masalah pasangan hidup karena jodoh itu urusan Tuhan Yang Maha Esa".

Orang tua merupakan kunci motivasi dan keberhasilan anak remaja, tidak ada pihak lain yang dapat menggantikan peranan orang tua seutuhnya. Keberhasilan orang tua dalam menunjang motivasi terletak pada keeratan hubungan antara orang tua dan anak dan yang terpenting bahwa suasana keluarga yang positif bagi motivasi adalah keadaan yang menyebabkan anak atau remaja merasa aman dan damai bila berada di tengah keluarga tersebut. Remaja merupakan masa peralihan antara masa anak dengan dewasa yaitu antara 12 sampai 21 tahun (Gunarsa, 2002). Remaja merupakan periode transisi antara masa anak ke masa dewasa atau masa belasan tahun atau seseorang yang menunjukkan tingkah laku tertentu seperti tidak mudah untuk diatur, mudah terpengaruh perasaan (Sarwono, 2005). Masa remaja diartikan sebagai masa perkembangan transisi antara anak dan masa dewasa yang mencakup perubahan biologis, kognitif dan sosial-emosional. Masa remaja adalah masa penting dalam hal prestasi, sesuai dengan pernyataan Henderson \& Dweck dalam Santrock (2003) mengatakan bahwa remaja merupakan masa penting dalam hal prestasi. Tekanan sosial dan akademis mendorong remaja kepada peran yang harus dibawa. Peran seringkali menuntut tanggung jawab lebih besar. Prestasi menjadi sangat penting bagi remaja, dan remaja mulai menyadari bahwa pada saat inilah dituntut menghadapi kehidupan yang sebenarnya.

Sangat perlu memiliki kompetensi sikap remaja seperti berikut: 1) kejelasan tujuan yang akan diraih. Semakin jelas sebuah tujuan maka akan mampu mengarahkan pada sebuah sikap yang harus terus secara konsisten dibangun walau banyak rintangan yang muncul dalam perjalanan itu; 2) memiliki niat kuat mencapai tujuan. Niat atau dorongan hati menjadikan seseorang terus melakukan apa yang diyakini dalam niat tersebut. Dorongan hati untuk mengejar impian yang akan mendisiplinkan diri, agar terus berupaya menapaki jalan menuju impian tersebut; 3) penetapan skala prioritas. Seseorang yang berkeinginan kuat mencapai impian maka harus memilih sebuah sikap secara selektif dan tidak sembarangan mempergunakan waktu; 4) tekun dan sabar menapaki jalan sukses yang diyakini. Ketekunan dan kesabaran akan membuahkan hasil yang gemilang karena ketekunan dapat membuat 
seseorang bersedia untuk terus belajar dari sebuah kesalahan dan kegagalan. Beragam masalah yang menghadang akan dinilai sebagai sebuah cara untuk meningkatkan kompetensi dan kemampuan dalam menggapai mimpi yang diinginkan.

Motivasi ada dua yaitu motivasi intrinsik berdasarkan pada faktor internal seperti determinasi diri, rasa ingin tahu, tantangan dan usaha. Motivasi ekstrinsik melibatkan insentif eksternal seperti penghargaan dan hukuman (Santrock, 2009). Kedua faktor motivasi tersebut saling berkaitan karena seseorang memliki rasa ingin tahu yang tinggi dan ingin memperoleh pengakuan di lingkungan. Memotivasi anak remaja diharapkan bisa tumbuh terhadap kebiasaan yang baik. Mengupayakan bagaimana anak mampu menumbuhkan motivasi internal yaitu yang datang dalam diri sendiri, yang muncul dari kesadaran sendiri.

Pemotivasian orang tua ke anak remaja adalah menyadarkan para generasi muda sebagai generasi penerus bangsa sesuai peran dan tanggung jawab, tidak bersifat egois, bertindak bijak, dan menjadi ujung tombak kesuksesan bangsa dan negara. Berdasarkan aspek regenerasi maka persoalan pembinaan remaja menjadi penting. Sebagai generasi penerus cita-cita perjuangan bangsa bahwa remaja lebih diarahkan dan dipersiapkan sedemikian rupa sehingga benar-benar merupakan jaminan kelangsungan hidup berbangsa dan bernegara serta mempunyai nilai-nilai agama yang luhur, sehingga energi yang dimiliki remaja dapat dialihkan pada halhal positif dan terhindar dari perilaku seksual pranikah. Pemotivasian yang diberikan orang tua akan membentuk karakter pada diri anak remaja. Karakter merupakan standar yang terimplementasi dalam berbagai bentuk kualitas diri. Karakter diri dilandasi nilai-nilai serta cara berpikir berdasarkan nilai tersebut dan terwujud dalam perilaku. Unsur penting pembentukan karakter adalah pikiran. Dalam pikiran terdapat seluruh program terbentuk dari pengalaman hidup individu. Program ini kemudian membentuk sistem kepercayaan yang dapat membentuk pola berpikir yang mempengaruhi perilaku. Jika program yang tertanam sesuai dengan prinsip kebenaran universal maka perilaku akan berjalan selaras dengan hukum alam dan hasilnya membawa ketenangan dan kebahagiaan. Sebaliknya, jika program tersebut tidak sesuai dengan prinsip hukum universal maka perilaku individu dapat membawa kerusakan dan penderitaan. Perilaku seksual tidak sesuai toleransi berdampak terhadap masa depan responden karena dapat terjadi kehamilan di luar nikah dan PMS termasuk HIV/ AIDS (Wang, 2007).

\section{Pendidikan Karakter Remaja Oleh Keluarga/ Orang Tua Ke Peneladanan}

Hasil penelitian indikator peneladanan orang tua (tabel 1) menunjukan bahwa sebagian besar responden tidak pernah mendapatkan peneladanan dari orang tua untuk pencegahan perilaku seksual pranikah sebanyak 135 responden $(59,0 \%)$ yang paling dominan dari pernyataan "orang tua saya mau belajar menjadi orang tua yang lebih baik dan dicintai anaknya". Pendidikan adalah proses mempengaruhi remaja agar dapat menyesuaikan diri sebaik mungkin terhadap lingkungan sehingga menimbulkan perubahan dalam diri yang berfungsi secara akurat dalam kehidupan masyarakat. Sikap pribadi anak sangat dipengaruhi oleh lingkungan keluarga karena sikap tindakan yang dilakukan oleh orang tua akan menjadi cerminan bagi anak. Hasil penelitian menjelaskan bahwa peranan keluarga berpengaruh tinggi terhadap perilaku seksual pranikah pada remaja. Berdasarkan hasil tersebut dinyatakan bahwa semakin tinggi peran keluarga pada remaja maka perilaku seksual pranikah remaja semakin baik dan sebaliknya (Darmasih, 2009).

Peran orang tua dalam keluarga sangat penting bagi anak, karena dengan peran yang dimiliki oleh orang tua tersebut maka dapat mempengaruhi perilaku anak. Ketika anak ingin berperilaku maka anak akan menyesuaikan perilaku dengan perilaku orang di sekitar. Apabila orang tua menjalankan peran dengan baik yaitu memberikan contoh perilaku yang baik dan benar maka akan mempengaruhi anak untuk bertindak atau berperilaku yang sama dengan kedua orang tua. Perkembangan masa anak adalah masa meniru dan mencontoh, melihat, dan mendengar sehingga ditiru oleh anak (Afra, 2011).

Teori interaksi atau perkembangan ditemukan oleh Piaget. Menurut Piaget bahwa anak itu membangun pengetahuan melalui interaksi dengan lingkungan. Anak bukan objek penerima pengetahuan yang pasif, melainkan dengan aktif melakukan pengaturan pengalaman ke dalam struktur mental yang kompleks. Hal ini ditandai dengan kesadaran orangtua tentang memberikan contoh yang baik bagi anak dengan menjaga dan memperhatikan perkatan, sikap, dan perbuatan di depan anak. Orang tua menyadari bahwa anak belajar terhadap apa yang dilihat dan didengar dari lingkungan keluarga dan lingkungan sekitar. Bahwa lingkungan keluarga merupakan lingkungan awal bagi anak, segala tingkah laku maupun perkembangan yang muncul pada diri anak, akan mencontoh pada kedua orang tua. Jika orang tua dapat memberikan contoh dan teladan yang baik bagi anak maka sikap anak tidak jauh beda dari 
orang tua dan apabila orang tua tidak dapat memberikan contoh yang baik, maka orang tua tidak bisa berharap bahwa anak akan lebih baik dan sesuai dengan keinginan orang tua.

Menurut Erikson bahwa pada masa remaja harus menemukan identitas diri. Erikson mencari gaya dan pola hidup sendiri yang dikenal dan berlangsung mapan. Pada waktu menjalani dan mengalami perubahan, pertumbuhan badan, dan kematangan seksual yang baru, remaja mempertanyakan pandangan orang tentang dirinya maupun pandangan dirinya. Peranan dan kemampuan memerlukan orientasi baru pada tuntutan dan persiapan penempatan posisi di masyarakat. Pada kondisi demikian remaja memerlukan tokoh identifikasi yang patut dijadikan model bagi remaja. Berdasarkan semua nilai dan norma yang diperoleh akan terbentuk falsafah hidup sebagai pegangan dalam pengendalian gejolak dorongan dalam diri remaja. Orang tua berperan dalam pembentukan nilai dan karakter dan perlu upaya, peranan dan strategi penumbuhan dan pengembangan pendidikan karakter remaja dan orang tua harus memiliki keteladanan karena keteladanan menggambarkan secara nyata bagaimana seseorang harus bertindak. Keteladanan berarti kesediaan setiap orang menjadi contoh dan miniatur yang sesungguhnya dari sebuah perilaku (Gunarsa, 2001).

\section{Pendidikan Karakter Remaja Oleh Keluarga/ Orang Tua Ke Pembiasaan}

Hasil penelitian indikator pembiasaan orang tua (tabel 1) menunjukkan bahwa sebagian besar responden sering mendapatkan pembiasaan dari orang tua untuk pencegahan perilaku seksual pranikah sebanyak 114 responden (49,8\%), yang paling dominan dari pernyataan "orang tua saya berusaha menjadi orang tua yang baik yaitu dengan membimbing dan memberikan perhatian terutama dalam hal cara bergaul dengan lawan jenis". Pembiasaan dapat membentuk karakter. Karakter tersusun dari tiga bagian yang saling berhubungan yaikni: moral knowing (pengetahuan moral), moral feeling (perasaan moral), dan moral behaviiour (perilaku moral). Karakter yang baik terdiri dari pengetahuan tentang kebaikan (knowing the good), keinginan terhadap kebaikan (desiring the good), dan berbuat kebaikan (doing the good), sehingga diperlukan pembiasaan pemikiran (habits of the mind), pembiasaan dalam hati (habits of the heart), dan pembiasaan dalam tindakan (habits of the action).

Menurut hasil penelitian Padila, Walker \& Thomson (2005) mengungkapkan ada strategi yang digunakan untuk memberikan pesan kepada anak yaitu reasoned cocooning yaitu orang tua secara persuasive melindungi anak dari pengaruh luar, memperkuat nilai-nilai keluarga pada anak dan memberikan penjelasan yang logis terhadap nilai-nilai yang ditanamkan sehingga menjadi suatu pembiasaan (Allison, 2004)

\section{Pendidikan Karakter Remaja Oleh Keluarga/ Orang Tua Ke Penegakan Aturan}

Hasil penelitian indikator penegakan aturan oleh orang tua (tabel 1) menunjukan bahwa sebagian besar responden jarang mendapatkan penegakan aturan dari orang tua untuk pencegahan perilaku seksual pranikah yaitu sebanyak 124 responden (54.1\%), yang dominan dari pernyataan "orang tua saya membuat kesepakatan bersama tentang penegakan aturan". Penegakan aturan di rumah akan membentuk kedisiplinan. Kedisiplinan merupakan kunci untuk mengantarkan remaja menjadi pribadi yang mandiri karena dengan disiplin remaja memiliki pola hidup tertata dan teratur, mampu mengembangkan kepribadian positif. Menurut Sutirna (2014) bahwa disiplin sangat penting diajarkan pada remaja untuk mempersiapkan remaja belajar hidup sebagai makhluk sosial. Hasil penelitian Kiprop \& Chaterine (2012) menyimpulkan bahwa untuk memperoleh kedisiplinan yang efektif harus melibatkan semua unsur termasuk remaja dan orang tua, harus bekerja sama dengan baik serta menjaga komunikasi satu sama lain dan bersikap terbuka agar memudahkan pencapaian kedisiplinan yang diharapkan.

Proses pembentukan atau pengembangan karakter diperlukan pendisiplinan. Disiplin berasal dari Bahasa Latin "discere" yang berarti belajar. Dari kata ini timbul kata "disciplina" artinya pengajaran. Disiplin mengalami perkembangan makna dalam beberapa pengertian: 1) sebagai kepatuhan terhadap peratuaran (hukum) atau tunduk pada pengawasan, dan pengendalian; 2) disiplin sebagai latihan bertujuan mengembangkan diri agar dapat berperilaku tertib; 3) kedisiplinan merupakan sikap mental yang mengandung kerelaan mematuhi semua ketentuan, peraturan, dan norma yang berlaku dalam menunaikan tugas dan tanggung jawab.

Untuk memperoleh kedisiplinan yang efektif harus melibatkan semua unsur termasuk remaja dan orang tua, harus dapat bekerja sama dengan baik serta menjaga komunikasi satu sama lain dan bersikap terbuka agar memudahkan pencapaian kedisiplinan yang diharapkan.

Hasil penelitian Zecevic (2010) 
menyimpulkan bahwa orang tua berpengaruh besar terhadap segala aktivitas yang dilakukan anak. Hal ini dibuktikan dengan orang tua yang mengetahui dan berkontribusi dalam jadwal sehari-hari, orang tua mendukung segala aktivitas positif yang dilakukan anak sehingga orang tua mengetahui sejauh mana perkembangan anak. Anak yang mendapat dukungan dan perhatian dari orang tua 6,3 kali lebih aktif dari pada anak yang kurang perhatian. Hal ini berarti perhatian dan dukungan orang tua berpengaruh terhadap perkembangan perilaku anak.

Fungsi utama disiplin adalah mengajarkan cara mengendalikan diri dengan mudah, menghormati, dan mematuhi otoritas atau peraturan yang ada. Pemberian hukuman terhadap pelanggaran harus ditetapkan berdasarkan aturan yang berlaku. Rumusan berat ringannya hukuman harus terlebih dahulu berdasarkan pertimbangan logis dan adil. Keputusan belum didasarkan pada pemikiran yang luas. Pengawasan orang tua dilakukan bertujuan agar remaja tidak berperilaku bertentangan dengan norma masyarakat. Orang tua perlu mengingat bahwa anak remaja membutuhkan kemandirian sehingga pengawasan yang dilakukan tidak berlebihan, misalnya ketika anak akan bermain maka orang tua cukup untuk membuat kesepakatan waktu pulang dengan anak. Peran orang tua dalam memberikan kebebasan kepada anak remaja harus diikuti dengan menanamkan rasa tanggung jawab. Setiap keputusan remaja akan membawa konsekuensi positif dan negatif. Alternatif konsekuensi yang timbul dari keputusan remaja seharusnya didiskusikan orang tua dengan anak remaja.

\section{SIMPULAN}

Temuan penelitian ini menunjukan bahwa remaja harus mendapatkan pendidikan seksualitas dari orang tua. Pendidikan seksualitas pada anak oleh orang tua diharapkan anak dapat terhindar dari perilaku seksual pranikah (Cheryl, 2013). Mengingat beratnya konsekuensi negatif yang berhubungan dengan perilaku seksual pranikah, memastikan bahwa remaja menerima pendidikan seksualitas penting untuk perkembangan yang sehat. Para peneliti telah menemukan bahwa orang tua merupakan pendidik seksualitas utama bagi anak. Penelitian lain menunjukkan bahwa remaja yang memiliki hubungan positif dengan orang tua akan menurunkan perilaku beresiko termasuk inisiasi dini hubungan seksual sehingga orang tua sebagai pendidik sangat penting untuk perkembangan remaja yang sehat (Resnick et al., 1997).
Orang tua berkewajiban dalam perkembangan sosial anak melalui aturan, sikap dan tindakan yang dicontoh anak dari orang tua. Pendidikan pertama didapatkan dari keluarga sehingga komunikasi orang tua dengan anak sangat diperlukan. Komunikasi orang tua dapat mencegah perilaku seksual remaja beresiko tinggi. Komunikasi seksualitas orang tuaanak dapat membentuk perilaku seksual yang bertanggung jawab pada anak, terutama menanamkan nilai-nilai moral. Komunikasi antara orang tua dan remaja biasanya berhubungan dengan masalah yang dihadapi oleh remaja dan menjadi tanggung jawab orang tua. Berkomunikasi dalam hal seksualitas, peran orang tua sangat penting dalam memberikan wawasan yang tepat atas pertanyaan berhubungan dengan masalah seksual. Bila orang tua tidak mampu melakukan maka anak akan mencari tahu informasi dari luar rumah seperti internet, film, dan teman (DiIorio et al., 1999). Informasi seksualitas sangat diperlukan oleh remaja untuk menghadapi masa gejolak seksual sehingga orang tua menjadi sumber informasi tentang seksualitas untuk mencegah rasa ingin tahu remaja terhadap seksualitas dari sumber yang tidak bertanggung jawab.

Pendidikan karakter remaja di keluarga berupa pengajaran, pemotivasian, pembiasaan, peneladanan dan penegakan aturan oleh orang tua. Pengajaran dalam konteks pendidikan karakter di keluarga diartikan sebagai upaya yang dilakukan oleh orang tua untuk memberikan pengetahuan kepada anak tentang nilai-nilai karakter tertentu dan membimbing serta mendorong untuk mengaplikasikan nilai-nilai tersebut dalam kehidupan sehari-sehari. Megawati (2005) menyatakan bahwa karakter merupakan tabiat seseorang yang langsung di-drave oleh otak (pengetahuan). Sedangkan karakter seseorang adalah sesuatu yang dikerjakan berdasarkan kesadaran yang utuh yaitu sesuatu yang diketahui secara sadar, dicintai dan diinginkan. Hal ini menunjukkan bahwa pengajaran memberikan pengaruh besar dalam pembentukan karakter anak di keluarga. Fungsi orang tua sebagai pendidik dalam keluarga adalah yang pertama dan utama karena orang tua adalah orang yang paling dekat dan penuh tanggung jawab terhadap proses pendidikan anak sejak dalam kandungan hingga usia dewasa, selain sebagai pendidik dalam keluarga, orang tua juga berfungsi sebagai sumber informasi atau pengetahuan yang baik dan benar bagi anak (Joar et al., 2015).

\section{KEPUSTAKAAN}

Afra, A., \& Supriyanto, A. 2011. Pendidikan Seks 
Untuk Remaja. Surakarta: Gizone Publishing.

Ali, M., \& Ansori, M. 2008. Psikologi Remaja Perkembangan Peserta Didik. Jakarta: PT Bumi Aksara.

Allison, Barbara, N., Schultx, \& Jerelyn, B. 2004. Parent-adolescent conflict in early adolescence. Adolescence, 39(153), 101-119.

Amirullah. 2015. Teori Pendidikan Karakter Remaja dalam Keluarga. Bandung: Alfabeta.

Byrne, BM. 2013. Structural Equation Modeling with AMOS: Basic Concepts, Applications, and Programming. New York, NY: Routledge.

BKKBN. 2010. Penyiapan Kehidupan Berkeluarga Bagi Remaja. Jakarta: Direktorat Remaja dan Perlindungan Hak-hak Reproduksi.

Cheryl, L., Somers, Claudia, \& Anagurthi. 2014. Parents' attitudes about adolescents' premarital sexual activity: The role of inter-parent consistency/inconsistency in sexual outcomes. Health Education Journal, Vol. 73(5) 545-553.

Darmasih, R. 2009. Faktor yang mempengaruhiPerilaku Seks Pranikah Pada Remaja SMA di Surakarta. Surakarta: Universitas Muhammadiyah Surakarta.

DiIorio, C., Kelley, M., \& Hockenberry-Eaton, M. 1999. Communication about sexual issues: Mothers, fathers, and friends. Journal of Adolescent Health, 24: pp.181-189.

Friedman, MM. 2003. Buku Ajar Keperawatan Keluarga: Riset, Teori. Jakarta: EGC.

Gunarsa, DS. 2006. Psikologi Perkembangan Anak dan Remaja. Jakarta: Gunung Mulia.

Hasanah, A. 2012. Pendidikan Karakter Berperspektif Islam. Bandung: Insan Kominika.

Joar, Svanemyr, Amin, A., Omar, J., Robles, \& Margaret EG. 2015. Review article Creating an Enabling Environment for Adolescent Sexual and Reproductive Health: A Framework and Promising Approaches. Journal of Adolescent Health 56 S7eS14.

Kiprop \& Chaterine, J. 2012. Approaches to Management of Discipline in Secondary Schools in Kenya. International Journal of Reasearch in Management 2(2) ISSN 2249-5908.

Kirby, D. 2011. Sex education: Access and impact on sexual behavior of young people. New York: United Nations Expert Group Meeting on Adolescents, Youth and Development.

Lickona, T. 1992. Educating for character: How Our Schools Can Respect and Responsibility. New York: Bantam Books.
Makol-Abduh. 2009. Parent's attitudes toward inclusion of sexuality education in malaysian school. International journal about parents in education. 3 (1), 42-56. Malaysia: international Islamic University Kuala Lumpur.

Maryatun \& Purwaningsih, W. 2012. Hubungan Pengetahuan dan Peran Keluarga dengan Perilaku Seksual Pranikah pada Remaja Anak Jalanan di Kota Surakarta. GASTER, Vol. 9, No. 1.

Megawati, R. 2005. Pendidikan Karakter: Solusi Tepat untuk Membangun Bangsa. Bogor: Indonesia Heritage Foundation.

Nurhayati. 2011. Hubungan Pola Peran, Komunikasi, Nilai dan Norma Keluarga dengan perilaku seksual remaja sekolah lanjutan tingkat atas di Kabupaten bekasi. Tidak diterbitkan. Tesis. Program Studi Magister Ilmu Keperawatan Kekhususan Keperawatan Ilmu Keperawatan Universitas Indonesia.

Nurkhasanah, T. 2015. Pengaruh Pendidikan Seks terhadap tingkat Pengetahuan dan Sikap Remaja dalam Pencegahan Seks Pranikah Di SMKN 2 Sewon Bantul Yogyakarta. Stikes Aisyiyah Yogyakarta.

Pratama, E. 2014. Hubungan Pengetahuan Remaja Tentang Pendidikan Seks Dengan Perilaku Seks Pranikah Pada Remaja Di SMA Z Kota Bandung. Jurnal keperawatan. Vol II no. 2.

Qudsy, HE. 2012. Ketika anak bertanya tentang seks (Panduan Islami Bagi Orang Tua Mendampingi Anak Tumbuh Menjadi Dewasa). Solo: Tiga Serangkai.

Rahmawati, CD. 2017. Perilaku Pencegahan Seks Pranikah pada Remaja SMA. Fakultas Kesehatan Masyarakat, Universitas Airlangga.

Resnick, MD., Bearman, PS., Blum, RW., Baurman, KE., Harris, KM., Jones, J., Tabor, J., Beuhring, T., Sieving, RE., Shew, M., Ireland, M., Bear-inger, LH., \& Udry, JR. 1997. Protecting adolescents from harm: Findings from the National Longitudinal Study on Adolescent Health. Journal of the American Medical Association, 278, 823-832.

Santrock, JW. 2002. Life-span development: perkembangan masa hidup (jilid 2). Jakarta: Erlangga.

Sarwono, SW. 2005. Psikologi Remaja. Jakarta: PT Raja Grafindo Persada.

Sukaedah, E. 2001. Faktor-Faktor Yang Berhubungan Dengan Sikap Terhadap Kesehatan Reproduksi Remaja Pada Siswa Kelas Dua 
SMU Negeri Kota Tangerang. Depok: Tesis Universitas Indonesia.

Sutirna. 2014. Perkembangan dan Pertumbuhan Peserta Didik. Yogyakarta: CV Andi Offset. Wang, B. 2007. Sexual attitudes, pattern of communication, and sexual behavior among unmarried out-of-school youth in China. BMC Public Health, 7: 189.

Zecevic, \& Cheryl, A. 2010. Parental Influence on Young Children's Physical Activity". International Journal of Pediatrics, 10.1155/2010/ 468526. 